\title{
Trophic linkages across seascapes: subtidal predators limit effective mussel recruitment in rocky intertidal communities
}

\author{
Gil Rilov ${ }^{1,2, *}$, David R. Schiel ${ }^{1}$ \\ ${ }^{1}$ Marine Ecology Research Group, School of Biological Sciences, University of Canterbury, Private Bag 4800, \\ Christchurch, New Zealand \\ ${ }^{2}$ Present address: Department of Zoology, Cordley 3029, Oregon State University, Corvallis, Oregon 97331-2914, USA
}

\begin{abstract}
Food-web linkages between habitats across a landscape are known to be important in terrestrial systems. Linkages through the lower (nutrients) and higher (predators) trophic levels are also starting to be recognized across seascapes. Here, we test the potential importance of a subtidalintertidal trophic linkage through predation on mussel recruits by fish in mussel-dominated communities at 2 tidal levels on wave-exposed shores of southern New Zealand. We show that on rocky shores that include both intertidal benches and subtidal reefs, labrid fish move into the intertidal zone during high tide and exert fast and strong predation pressure on small mussels in the low-, and to a lesser extent mid-shore, intertidal levels. Within $1 \mathrm{~d}, 80$ to $95 \%$ of small (5 to $15 \mathrm{~mm}$ ) transplanted mussels were removed from experimental tiles on the low shore when unprotected from fish predation, while 20 to $60 \%$ were removed on the mid-shore; in contrast, most fully protected mussels survived for months. Although at a slower pace, predation was also evident in cages that excluded fish but allowed access to large invertebrate predators. This predation occurred mostly at night when large predatory crabs were abundant at the study sites. The combined predation pressure on small mussels by fish and crabs was reflected in the scarcity of larger/older mussel recruits (5 to $15 \mathrm{~mm}$ ) outside mature beds on the low shore compared to greater abundance on the mid-shore. The number of mussel settlers in artificial collectors and of smaller/younger recruits $(<5 \mathrm{~mm})$ within barnacle patches did not significantly differ between shore heights; thus, we attribute the difference in abundance of late recruits to differential predation rates by subtidal predators. This study clearly demonstrates that highly mobile subtidal predators, particularly fish, can have important impacts on temperate intertidal food webs, especially on early life stages of habitat-dominating invertebrates, such as mussels in New Zealand and probably elsewhere.
\end{abstract}

KEY WORDS: Food web $\cdot$ Mussels $\cdot$ Crabs $\cdot$ Recruitment $\cdot$ Subtidal-intertidal $\cdot$ New Zealand Resale or republication not permitted without written consent of the publisher

\section{INTRODUCTION}

Food web linkages between adjacent habitats within a single landscape are common in nature, but are usually described in relation to energy flow through the lower trophic levels (e.g. nutrient-based or detritalbased terrestrial-aquatic linkages; Wootton 1991, Polis et al. 1997). Trophic linkages can also occur by movement of predators throughout a landscape. In some ter- restrial landscapes, consumers move from their primary habitat to others nearby to forage (e.g. nest and seed predators from open habitats feed at the forest edge; Kollman \& Buschor 2003). Trophic linkages also occur across seascapes, but their nature and importance have not been well demonstrated.

The concept of 'seascape ecology' was borrowed from terrestrial landscape ecology by Bartlett \& Carter (1991). Jones \& Andrew (1993) expanded on this, and 
stressed the potential importance of linkages (including trophic ones) among patches and habitats in temperate seascapes. Linkages through the higher trophic levels (habitat determiners such as predators, sensu Jones \& Andrew 1993) are recognized across seascapes; however, to date this aspect has rarely been addressed in temperate reef systems. For example, consumers that live on subtidal rocky reefs were shown to affect surrounding soft-bottom benthic assemblages on the North Carolina and Australian coasts (Lindquist et al. 1994, Barros et al. 2001), and 'infaunal haloes' around reefs (e.g. Davis et al. 1982) are thought to be associated with foraging reef predators such as fish.

Among marine habitats, the rocky intertidal zone represents an interesting case: it can be affected intermittently by predators from adjacent habitats, depending on the state of the tide. At low tide, prey in this zone can be foraged by seabirds from the air (Levings et al. 1986, Marsh 1986) or by mammals from land (e.g. Navarrete \& Casilla 1993, Stapp \& Polis 2003), and at high tide by mobile subtidal predators (Menge et al. 1986, Robles et al. 1990). For example, on some shores, lobsters move between the subtidal and intertidal zones across the rocky seascape during high tide, and can affect the intertidal community structure (southern California; Robles et al. 1990). Foraging activity of these and other subtidal predators such as crabs (e.g. Burrows et al. 1999) and fish should be somewhat hindered by wave action (environmental-stress models; Menge \& Sutherland 1987). However, for highly mobile species like fish, a few calm days or even hours might be sufficient to exert strong predation pressure on intertidal prey and influence community structure. Furthermore, these effects can be strongly influenced by the nature of the seascape around intertidal benches. Rilov \& Schiel (2006) showed that where intertidal platforms were contiguous with subtidal rocky reefs, predation by fish on mussels was much greater than on isolated intertidal benches. This effect was particularly strong on recently recruited mussels. However, they did not examine predator abundance or quantify fish foraging activity, nor did they test whether predation pressure varies with tidal height.

Fish can be important predators in tropical intertidal areas (Lubchenco et al. 1984, Menge et al. 1986). For example, Menge et al. (1986) found that the tropical mussel Modiolus capax was eliminated almost immediately when exposed to predation by fish. The effects of fish as predators on temperate reefs are equivocal, but observations indicate that intertidal mussels and snails are included in their diet (Edwards et al. 1982, Robles 1987, Ojeda \& Dearborn 1991). Edwards at al. (1982) stressed the need to experimentally test the effects of fish predation in intertidal communities, but so far there have been few such studies.
Southern hemisphere temperate shores and especially those of southern Australia and New Zealand have high diversity and abundance of shallow water predatory fishes, primarily labrids, monocanthids and sparids, and provide an interesting contrast to western North American shores where this fauna is poorly represented (Choat \& Schiel 1982), probably because their history was substantially impacted by glaciation (Hickerson \& Cunningham 2005). Such fishes, especially labrids, are common along eastern shores of $\mathrm{New}$ Zealand. The 2 most abundant of these are Notolabrus celidotus (spotty) and Notolabrus fucicola (banded wrasse) (Choat \& Ayling 1987, Jones 1988, Schiel \& Hickford 2001). Both are generally associated with macroalgal-dominated rocky reefs, where the juveniles use the algae as nursery and feeding grounds, and adults feed diurnally on macro-invertebrates found on the surrounding complex rocky habitats (Jones 1984a,b, Denny \& Schiel 2001). For northeastern New Zealand, Jones (1988) concluded that carnivorous fish do not play a major role in determining the biological structure of subtidal habitats or in modifying prey communities. However, most studies reviewed by Jones (1988) examined effects of fish on sea urchins, and he recognized that adequate experiments were still needed to confirm this general conclusion. The potential effects of these abundant predators have not been examined in intertidal assemblages. Nevertheless, $N$. celidotus is considered to be a subtidal pest on farms of the green-lipped mussel Perna canaliculus Gmelin because of its intense predation on small mussels (<20 mm; Hayden 1995). These fish clearly have the potential to influence intertidal communities as well, particularly in the low intertidal zone where mussels can be abundant and easily accessed by fish. Their effect may be particularly important on mussel recruits, and in areas where settlement rates are relatively low. Menge et al. (1999, 2002, 2003) conducted predation experiments on rocky outcrops where mussels are abundant on both the east and west coast of the South Island of New Zealand using relatively large transplanted mussels (30 to $50 \mathrm{~mm}$ ). They found strong predation effects by sea stars at west coast sites and no effects of predators at east coast sites. However, they did not test the potential effects of fish or other highly mobile predators like crabs on recruit mussels.

Our core hypothesis is based on the fact that shallow subtidal environments in New Zealand include a suite of fast, mobile predators that tends to be missing in most other biogeographic regions for which predation and its effects have been measured in the intertidal. Therefore, we tested the hypotheses that by foraging across the rocky seascape, fish would exert strong and differential effects on mussels at 2 tidal levels and that 
these effects would occur quickly and on recently recruited mussels. We anticipated that (1) predation effects would be greater on low- than mid-shore levels (because subtidal predators have more time to forage on the low shore), resulting in differential mussel size distribution across shore heights; (2) abundances of small mussels outside established beds would be higher in the mid- than in the low-shore, independent of settlement rates; (3) predation rates on small mussels would be greater when they are exposed to both fish and large benthic invertebrates than when they are exposed to invertebrate predation only (because benthic invertebrates are potentially less mobile than fish). In contrast to Rilov \& Schiel (2006), we used only sites that had intertidal and subtidal rocky reefs.

\section{MATERIALS AND METHODS}

Study sites and characterization of major space occupiers. For the first experiment in which we tested predation rates at 2 tidal levels, we used Black Rock (BR), a study site on Banks Peninsula near Christchurch (Fig. 1). For the second experiment, in which we compared predation rates by all large predators

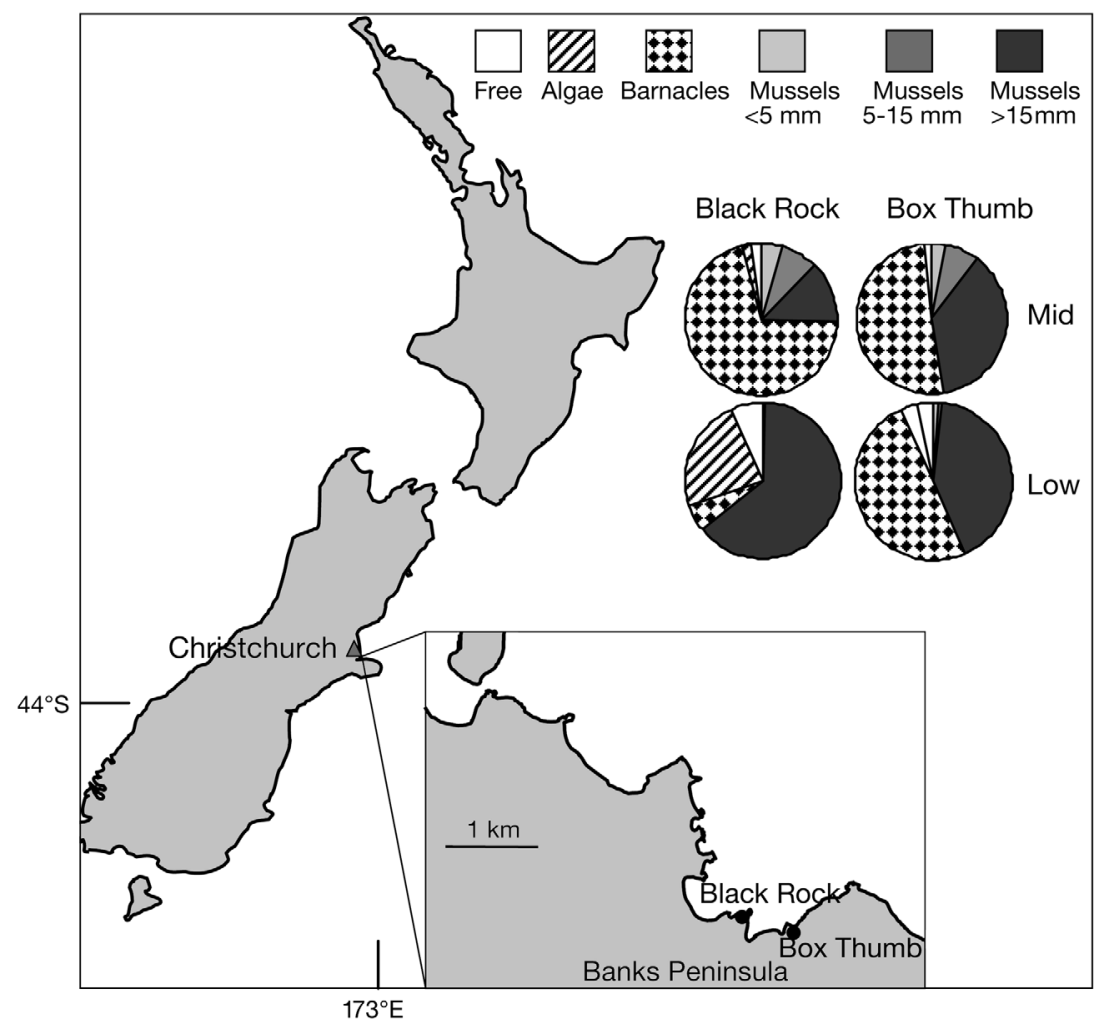

Fig. 1. Location of study sites, Black Rock (BR) and Box Thumb (BT), in New Zealand and \% cover of major space occupiers at low- and mid-shore levels (pie charts) at the 2 sites (data are an expanded subset of similar data in Rilov \& Schiel 2006) (fish and crabs) to rates by large invertebrates only (fish excluded), we used only the low zones at BR and the nearby Box Thumb (BT), a site also used by Menge et al. (1999, 2003). These wave-exposed sites are volcanic or hard metamorphic rock benches that extend underwater to create an extensive, rapidly sloping, subtidal reef. The structure of the adjacent subtidal reefs is complex, with lush subtidal brown algal vegetation and bull kelp Durvillaea spp. at the intertidal-subtidal fringe. Isolated mussel patches of various sizes occur throughout the low- and midintertidal zones. The maximum tidal range in the region is $\sim 2.4 \mathrm{~m}$. We define the low shore there as extending from 0 to $0.8 \mathrm{~m}$ (lowest astronomical tide, LAT) and the mid-shore from 0.8 to $1.6 \mathrm{~m}$.

To characterize the main space occupiers at our study sites, in April 2004 we estimated the \% cover of mussels of different size classes $(<5 \mathrm{~mm}, 5$ to $15 \mathrm{~mm}$, and $>15 \mathrm{~mm}$, the latter of which represents mature beds of large mussels), barnacles, algae (all types pooled) and 'free' space (bare rock or thin encrusting red algae, hereafter 'free space') in the middle parts of the low-shore and mid-shore levels. We used a $25 \times$ $30 \mathrm{~cm}$ quadrat (divided into $5 \times 5 \mathrm{~cm}$ squares) that was placed randomly along two $10 \mathrm{~m}$ transects laid parallel to the water's edge at each shore level ( $\mathrm{n}=10$ quadrats in each transect, i.e. $\mathrm{n}=20$ for each shore level).

Effect of subtidal predators on small mussels at different shore heights. A caging experiment was conducted at BR to determine the effects of macropredators on small mussels in the lowand mid-shore levels. The experimental units were late mussel recruits/small juveniles (5 to $15 \mathrm{~mm}$ shell length) on $5 \times$ $5 \mathrm{~cm}$ tiles with $4 \mathrm{~mm}$ thick nylon carpet glued to 1 surface, which provided a heterogeneous substratum for mussel attachment. Twenty-five mussels were placed onto each tile, which were then wrapped with plastic mesh to secure the mussels until most individuals were attached firmly. The relatively soft carpet surface also prevented the crushing of the mussels as the mesh was tightened by a stainless steel screw to the rock. Mussels were collected in midDecember 2002 from low-shore rocks at a nearby site. We used a mixture of Xenostrobus pulex Lamarck and Mytilus galloprovincialis Lamarck because they were by far the most abundant small mussels in the area outside established beds. 

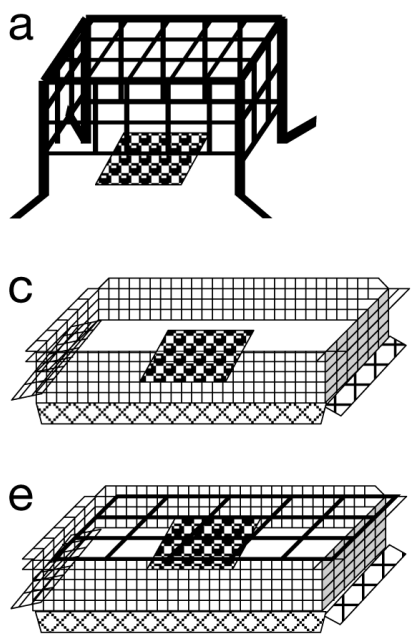

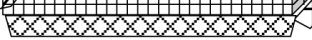

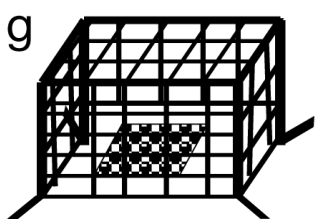

Fig. 2. Experimental treatment design: (a) Partial Cage (excludes fish); (b) Partial Cage Effect (accessible to all predators); (c) Fence (excludes whelks); (d) Fence Effect (accessible to all predators); (e) Full Cage (excludes all predators); (f) No Cage (accessible to all predators); (g) Full Cage (excludes all large predators but allows access to small whelks)

At this stage, we anticipated that fish and whelks would be the main predators of small mussels (because they were the only visible predators during low tide or snorkeling observations). Therefore, we used 3 levels of exclusion cages (Fig. 2): Full Cage (-fish -whelk) excluding all macro-predators, Partial Cage (-fish +whelk) excluding fish but allowing access to benthic macro-predators through a gap near the rock, and Fence (+fish -whelk) excluding whelks but allowing access to fish. We also had 3 levels of control: No Cage (+fish +whelk) exposing mussels to all predators, Partial Cage Effect (+fish +whelk) modified from fish cages, and Fence Effect (+fish +whelk) modified from whelk fences.

The frames of the fish exclusion cages were made from $6 \mathrm{~mm}$ steel rods: legs $10 \mathrm{~cm}$ high and sides $20 \mathrm{~cm}$ long. A rigid plastic mesh with holes of $16 \times 16 \mathrm{~mm}$ was wrapped around each cage. A gap of $3 \mathrm{~cm}$ was left between the mesh and the rock surface to allow access to whelks or other benthic predators (Fig. 2a). This mesh was meant to prevent access to large predatory fish and to minimize cage effects (such as reduction in light or water motion). Controls for these Partial Cages had the same design but no mesh on the top and 2 of the sides (Fig. 2b). To exclude whelks we built a $7 \mathrm{~cm}$ high $20 \times 20 \mathrm{~cm}$ square fence from rigid stainless steel mesh (gauge $=0.71 \mathrm{~mm}$, weave $=2.46 \mathrm{~mm}$ ), with the upper lip folded outward to prevent snails from climbing in (Fig. 2c). The whelk Fence control was a similar fence but with openings $10 \mathrm{~cm}$ long and $3 \mathrm{~cm}$ high on 2 sides (Fig. 2d). The Full Cage treatment was a complete cage made of the same stainless steel mesh (Fig. 2e). This Full Cage excluded all macro-predators. A single tile was placed into each cage or no cage treatment (Fig. 2f). Within a stretch of $\sim 25 \mathrm{~m}$, we located 5 plots in the low-shore $(0.4$ to $0.7 \mathrm{~m})$ and 5 in the mid-shore (1.1 to $1.5 \mathrm{~m})$. Within each plot we randomly placed 1 replicate of each treatment and control, with the constraints of finding suitable surfaces for securing the cages and with the lowest possible need to remove mussels from the plot. We cleared the rock surface within a $25 \times 25 \mathrm{~cm}$ area for each treatment/ control, and drilled holes for the cages and tiles that were placed in the middle of each cage or cleared area (for No Cage control: tile only). Treatments and controls in the plots were at least $30 \mathrm{~cm}$ apart in order to keep them independent. Experiments were placed far enough away from macroalgae that there could be no whiplash effect on mussels. The experiment was initiated during spring tide of 2 January 2003. After the removal of the mesh, between 15 and 25 live and wellattached mussels remained on each tile. These mussels formed the baseline for mussel survival from the start of the experiment (Day 0).

The numbers of live and dead/missing mussels were monitored daily at low tide over the next $4 \mathrm{~d}$, during which time the study site was observed for as long as it was exposed to air during daytime hours in order to watch for potential bird predation on experimental mussels. On Day 5 and for several days thereafter, the sea was too rough to monitor all treatments. Generally, for both experiments, monitoring was only possible on the low shore several days before and several days after spring tide, when the sea was relatively calm and lowshore mussels exposed to air. During the next spring tide, on Day 18, the experiment was monitored again. Some of the low-shore cages had been damaged by a storm and few mussels remained on the tiles, so we used only the data from the mid-shore for that date. For each day, the $\%$ survival was calculated from the initial number of mussels on tiles on Day 0. Differences in mussel survival among treatments and between shore heights were tested using data from Day 1, Day 4 and for the midshore only on Day 18. In another experiment conducted at BR in February 2003 (Rilov \& Schiel 2006), we tested whether mussels were more accessible to predators on experimental tiles than on bare rock by transplanting mussels directly onto the rock on the low shore. This experiment showed that unprotected mussels were removed at similar rates from the tiles and rock. 
Effect of fish and crab predation on mussel survival. During the first experiment it was clear that, besides fish, other predators that were not visible during our daily observations were eating mussels. The most likely candidates were large, mostly nocturnal crabs that may have crawled through the $3 \mathrm{~cm}$ gap between the mesh and rock, or reached mussels on tiles with their chelipeds. We excluded the possibility of whelk predation because whelks were rarely observed in the cages during either low or high tide and also because whelks usually leave an empty shell with a drill hole, whereas the mussels in our experiment had completely disappeared from the tiles. Therefore, in the second experiment, we repeated the exclusion of large fish using the Partial Cages, and this time excluded both fish and large invertebrate predators such as crabs using a full cage that had a similar design to the Partial Cage (i.e. the same frame and the same plastic mesh with $16 \times$ $16 \mathrm{~mm}$ holes, which in this case extended all the way to the rock surface; Full Cage, Fig. 2g). This design would allow most small whelks found in the study site to enter the Full Cage through the large holes in the mesh. The dimensions of cages in this experiment were $10 \times 10 \times$ $10 \mathrm{~cm}$. The experiment was conducted at BR and BT (March to May 2003). Late mussel recruits (5 to $15 \mathrm{~mm}$ ) were settled on tiles as described above on 25 February 2003, and all tiles were placed in a single location at BR. The experiment began on 19 March 2003 by translocating the tiles to their prospective treatments at both sites, and then by monitoring mussel survival on Days 1 to 3 , $6,8,12,16,29,44$ and 56. The BR site was also monitored by SCUBA during the first high tide, $4 \mathrm{~h}$ after the initiation of the experiment, by looking for fish activity near the mussels on tiles.

Abundance of small vs. large recruits and mussel recruitment rates at 2 shore heights: Barnacles can facilitate mussel recruitment (e.g. Lively \& Raimondi 1987). In areas of strong predation by large predators (fish, crabs), mussels that recruited between barnacle tests in areas of barnacle patches should be more vulnerable once they grow above the height of barnacle tests. According to Menge et al. (1999), recruitment did not appear to differ much between the low- and midshore in Banks Peninsula; thus, we expected to find similar numbers of early recruits $(<5 \mathrm{~mm})$ within barnacle patches in the 2 shore levels at BR and BT. However, densities of late mussel recruits in the 5 to $15 \mathrm{~mm}$ size range in the low shore were expected to be lower due to predation by large predators. To test this, all mussels were counted inside $10 \times 10 \mathrm{~cm}$ quadrats covered by barnacles in the gaps between patches of large mussels at these 2 sites ( $\mathrm{n}=20$ quadrats in each shore height). BR was sampled on 6 January 2003, near the peak of the recruitment season, and again on 23 March. BT was sampled only on the latter date.
To test for potential differences between shores zones, recruitment on the low- and mid-shore was measured from February to April in BR during the peak of the settlement season, the austral summer (Menge et al. 1999). This was done using collectors made of plastic-mesh, ovoid pot scrubbers ('tuffies', see Menge et al. 1994, 1999, 2003). Five collectors were fastened to the rocks at each shore level with stainless steel screws and washers and collected after 1 mo. Samples were stored frozen at $-20^{\circ} \mathrm{C}$ until analysis. In the laboratory, mussel recruits were extracted from the collectors as follows: a single collector was placed in a jar with $10 \%$ bleach solution for $4 \mathrm{~min}$ in order to dissolve byssal threads; the jar was shaken, and then the content was sieved through 3 mesh sizes (Hayden 1995). Mussels were identified to species when possible under a dissecting microscope and counted; for the purposes of the present study, however, all mussel species were pooled together.

Fish presence and activity during high tide. The presence of fish and their activity at sites with subtidal reefs near Christchurch were evaluated by snorkeling at BR and BT during a single high tide on 25 March 2003 during calm sea conditions. During three 5 min observations ( 5 min intervals between each), the number of predatory fish that visited an area $\left(\sim 20 \mathrm{~m}^{2}\right)$ was recorded in the low shore area where the experimental plots were situated. The number of bites that these species took off the benthos was also recorded.

Crab presence. Crab pots were set to determine if large predatory crabs were present at the sites. Preliminary trials showed that crabs were rarely caught during daytime (most predatory crabs are known to be nocturnal, e.g. Burrows et al. 1999); thus, sampling was done at night. On 5 June 2003, just before sunset, 5 crab pots (set at 3 to $4 \mathrm{~m}$ intervals) baited with crushed mussels were placed at both sites parallel to the rocky benches at 1 to $2 \mathrm{~m}$ depth. Pots were collected at sunrise and crabs were identified to species, counted, and their carapace width and height were measured.

Data analyses. When \% survival was used, data were arcsine square-root transformed (Sokal \& Rohlf 1995). For the first predation experiment we used an ANOVA (STATISTICA 6, StatSoft 2001) for Days 1, 4 and 18 (for mid-shore only) separately, with 'shore height' (for Days 1 and 4 only) and 'treatment', as fixed factors, and 'plot' as a random factor nested in shore height. For the second predation experiment we used a mixed-model ANOVA with 'site' and 'plot' (nested in site) as random factors, and Treatment (No Cage, Partial Cage, Full Cage etc.) as a fixed factor. In this model there is no test for the plot (within shore height) $\times$ treatment interaction, and this term became the residual. Survival was tested for each day separately. Two-way mixed-model ANOVA was used on the number of 
small and large recruits at the 2 shore heights, sites and dates (site and 'month' were treated as random factors), and on the settlement to different shore levels in BR (month treated as random factor). Homogeneity of variances was checked by Cochran's test. When variances were heteroscedastic, parametric analyses were still used because significance levels in the predation experiments were usually very high (allowing an assumption that the probability of Type I errors was low), but conclusions were conservative and based on the significance of $p$-values and sample size (e.g. Underwood 1997). In some experiments, Fisher's least significant difference (LSD) post-hoc analysis was used to test for significance among categories.

\section{RESULTS}

\section{Characterization of major space occupiers}

Both study sites were characterized by greater coverage of large mussels in the low- than in the midshore (Fig. 1). However, the cover of small mussels (<15 mm) was around $20 \%$ in the mid-shore and almost $0 \%$ on the low shore. Mature beds of large mussels were composed of a mixture of 2 large mussels, the green lipped mussel Perna canaliculus (maximum size $160 \mathrm{~mm}$ ), and the blue mussel Mytilus galloprovincialis (120 mm), and 2 smaller species, the ribbed mussel Aulacomya ater maoriana Iredale $(80 \mathrm{~mm})$, and the black mussel Xenostrobus pulex (30 mm), which were less visible because they were mostly in the understory of the larger mussels. Individuals and patches of small mussels $(<15 \mathrm{~mm})$ outside mature beds in the midshore, and individuals of small mussels on the low shore, were mostly of the small species $X$. pulex. Macroalgae and barnacles were also important components, the former mainly on the low shore of BR.

\section{Effect of predators at different shore heights}

Predation on small unprotected mussels was swift and strong. Mussel survival was poor on the low shore $(<20 \%)$, but higher on the mid-shore (40 to $80 \%)$, after just $1 \mathrm{~d}$ in all treatments that did not exclude fish. Few mussels remained on the low shore, but 20 to $40 \%$ remained on the mid-shore, after $4 \mathrm{~d}$. Therefore, overall, the treatment effect was highly significant (treatment effect: Day $1, F_{5,40}=15.8$; Day 4: $F_{5,40}$ $=21.5$; Day 18: $F_{5,40}=7.3, \mathrm{p}<0.0001$ for all; Fig. 3) as was shore height (shore height effect: Day 1: $F_{1,8}=$ 16.9, p $=0.0003 ;$ Day 4: $F_{1,8}=8.6, \mathrm{p}=0.02$; plot (within shore height) effect: Day 1: $F_{8,40}=2.7, \mathrm{p}=$ 0.02; Day 4: $F_{8,40}=4.2, p=0.0009 ;$ Fig. 3). The plot effect was mainly a result of relatively high survival rates in all treatments open for fish and crab predation at the 2 uppermost plots in the mid-shore, probably because these plots were too high up the shore to allow effective predation by these predators. In the Partial Cages, mussel survival was intermediate and lower than in the Full Cages, indicating that predators
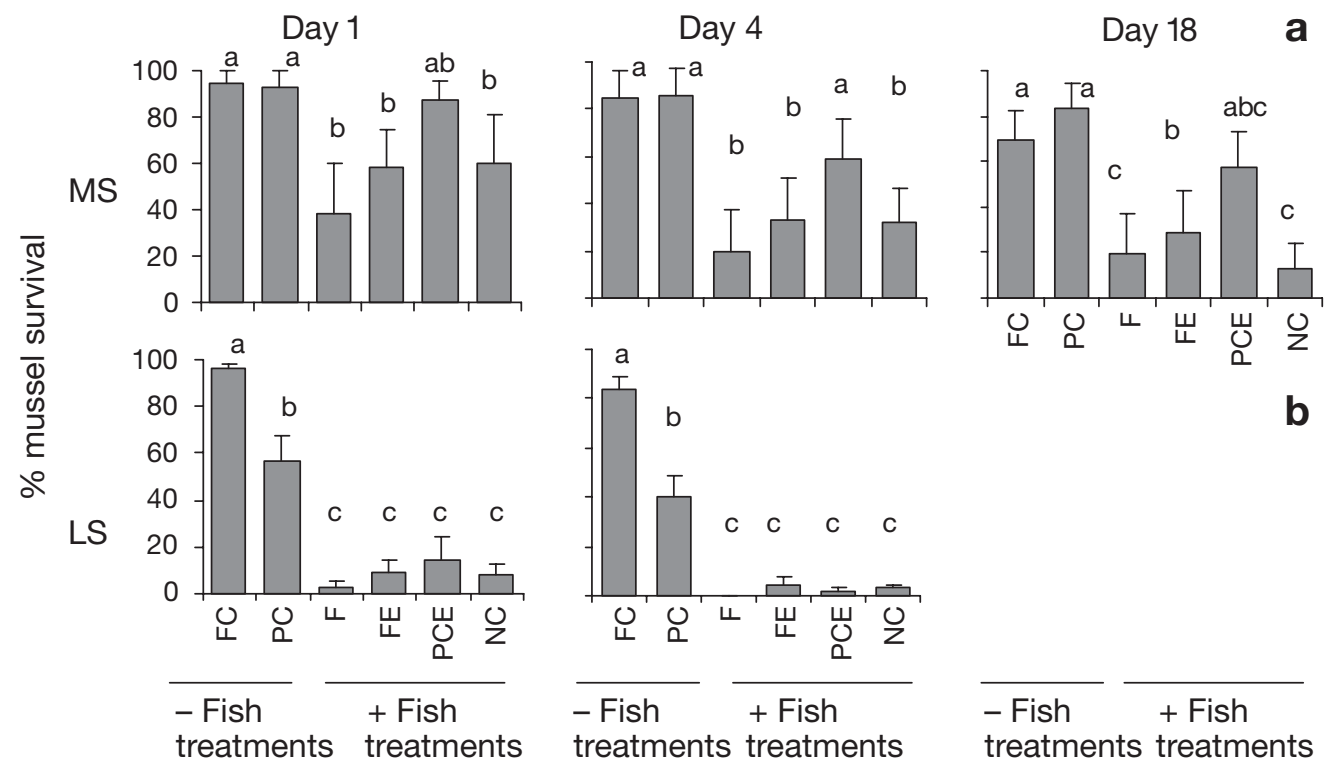

Fig. 3. Survival (mean $\pm \mathrm{SE}$ ) of mussels (5 to $15 \mathrm{~mm}$ ) at (a) mid-shore (MS) and (b) low-shore (LS) levels at BR, January 2003. Effects of predator exclusion; treatments with similar lowercase letters were not significantly different in post hoc analysis. -Fish treatments: treatments that protected mussels from fish predation; + Fish treatments: treatments that did not protect mussels from fish predation; FC: Full Cage; PC: Partial Cage; F: Fence; FE: Fence Effect; PCE: Partial Cage Effect; NC: No Cage 


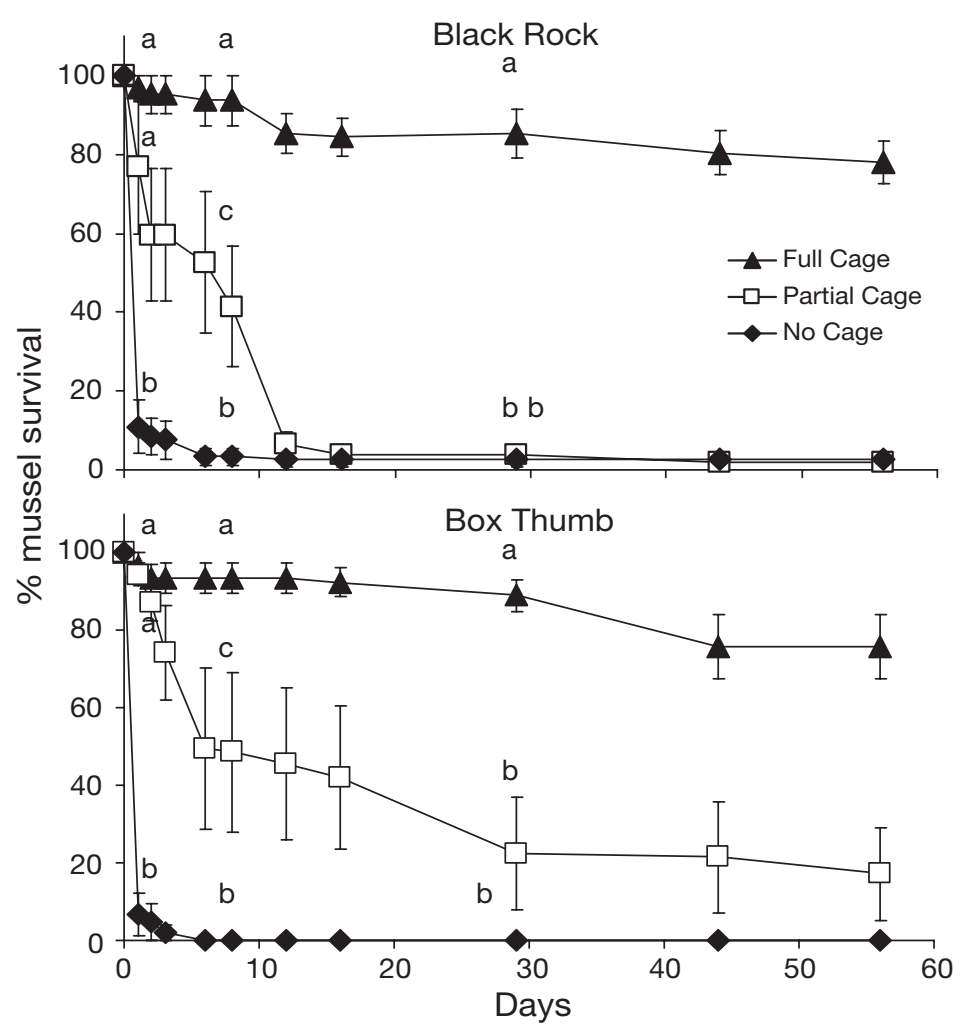

Fig. 4. Survival (mean $\pm \mathrm{SE}$ ) of mussels (5 to $15 \mathrm{~mm}$ ) exposed to all predators (No Cage), with fish excluded (Partial Cage), and with large predators excluded (Full Cage) at the low-shore level at BR and BT, March to May 2003. Treatments with similar lowercase letters were not significantly different in post hoc analysis

other than fish also affected mussels. Because the Partial Cage controls were similar to other controls (i.e. there was no cage effect apparent), this treatment was eliminated in the subsequent experiment. The mussels in this experiment were removed entirely and no dead mussels with drill holes were found, so it is unlikely that mussel mortality in the Partial Cages was due to whelks. Also, no whelks were ever seen eating experimental mussels. Furthermore, very few mussels remained in the Fence treatment in the low shore, and in the mid-shore area there was no difference between Fence and Fence Effect treatments, again suggesting no apparent whelk effect. Throughout the first $4 \mathrm{~d}$ of the experiment, no predation by birds was seen during daytime low tides. Shorebird activity was generally low at this site.

\section{Effect of fish and crab predation on mussel survival}

Over the $56 \mathrm{~d}$ of the second experiment there was $>80 \%$ mussel survival where all large predators were excluded (Full Cages, Fig. 4). Mussels exposed to all predators (No Cage) had $<10 \%$ survival within the first few days at both sites; in contrast, in the Partial
Cages, survival rates were more variable (larger SE) and declined more slowly, although eventually most mussels disappeared (Fig. 4). A treatment effect became apparent on Day 1 $\left(F_{2,2}=55.1, \mathrm{p}=0.017\right)$, and remained strong until the end of the experiment on Day 56. There were no site, plot, and site $\times$ treatment interaction effects throughout the experiment ( $p>0.15)$. On Day 1, there was already very poor survival in the fully exposed mussels, but survival was high in the Partial and Full Cages (Fig. 4, post hoc analysis). Survival in the Partial Cages began to differ significantly from the Full Cages by Day 8 and converged with the No Cage treatments by Day 29. During SCUBA observations, it was apparent that the highest mortality of mussels exposed to all predators occurred during the first daytime flood tide. Survival was $36.7 \pm 8.0$ (SE) after just $4 \mathrm{~h}$ for No Cage mussels at BR, while at the same time survival in the Partial and Full Cages was $94.7 \pm 2.6$ and $96.8 \pm 3.2$, respectively. A spotty Notolabrus celidotus was seen removing a mussel from a No Cage treatment and a banded wrasse $N$. fucicola removed 3 mussels from another open treatment, but no large crabs were seen. These observations support the notion that most predation of mussels occurred during daytime in the open treatment but at night in the Partial Cages.

Abundance of small vs. large recruits and mussels settlement rates at 2 shore heights. Small mussel recruits ( $<5 \mathrm{~mm}$ shell length) occurred in similar abundances at both tidal heights $\left(F_{1,76}=2.53, \mathrm{p}=\right.$ 0.35), but larger recruits (5 to $15 \mathrm{~mm}$ ) were far more numerous on the mid-shore, especially at BR (site $\times$ shore height interaction: $F_{1,76}=7.8, \mathrm{p}=0.007$, Fig. 5, Table 1). There was a significant increase in small recruits between January and March 2003 but no difference in larger recruits (Fig. 5, Table 1). Although there was an apparent trend towards slightly higher settlement on the mid- than the low-shore levels (insert, Fig. 5), this difference was not statistically significant $\left(F_{1,24}=10.01, \mathrm{p}=0.09\right)$. There were also no significant month or month $\times$ shore height interaction effects.

\section{Fish activity during high tide}

On average, $3.3 \pm 0.7$ spotties visited a $20 \mathrm{~m}^{2}$ area of the low shore at BT and $2.3 \pm 0.9$ at BR during 5 min observations. Their average number of bites was $6.0 \pm$ 3.0 and $0.3 \pm 0.3$, respectively. There were $2.7 \pm 0.9$ banded wrasses at BT and $0.7 \pm 0.3$ at BR (averages 


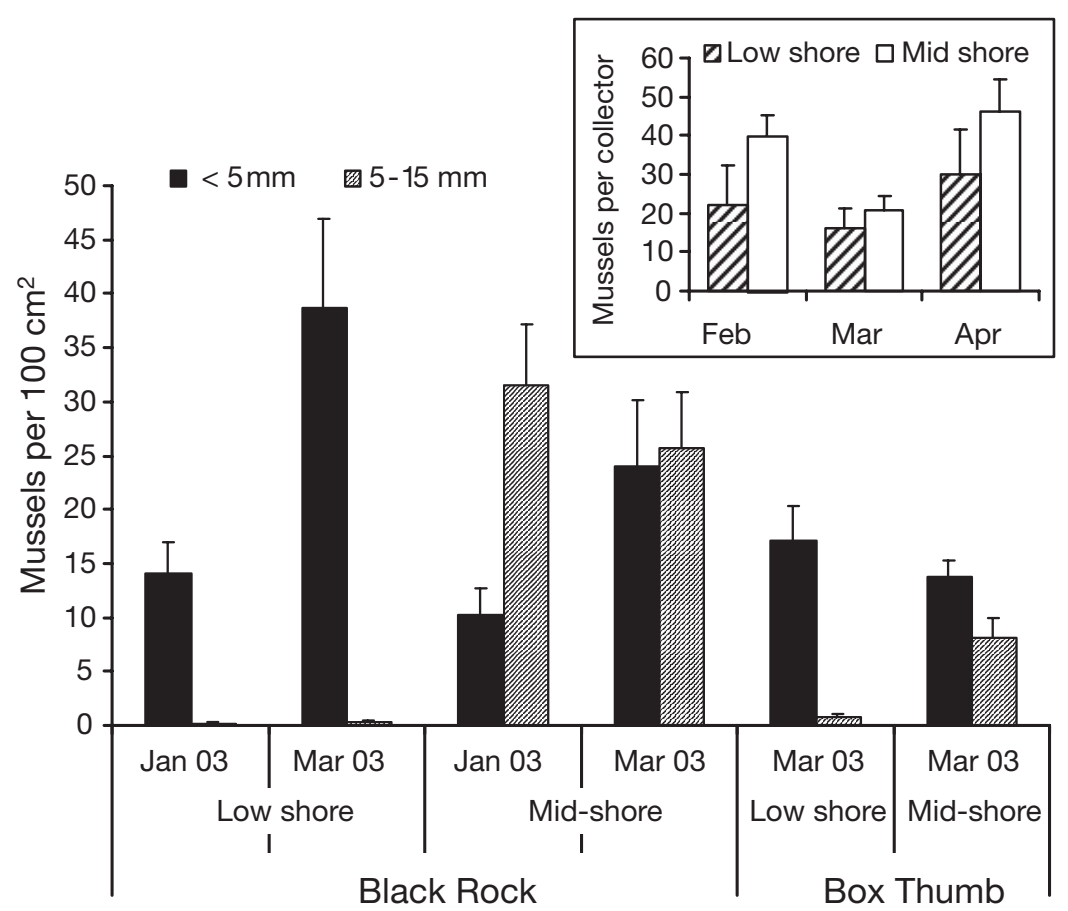

Fig. 5. Density (mean $\pm \mathrm{SE}$ ) of small $(<5 \mathrm{~mm}$ ) and larger (5 to $15 \mathrm{~mm}$ ) mussel recruits at sites with subtidal reefs. Effect of shore height (low- and mid-shore) and date (early January and late March 2003). Insert: recruitment (mean \pm SE number per collector) of mussels into mussel collectors (tuffies) in the low- and mid-shore levels in February, March and April 2003

\section{DISCUSSION}

This study shows that predation by fish and crabs can have a strong and rapid effect on young mussels, thereby demonstrating a significant top-down linkage between subtidal and intertidal habitats across a single continuous rocky seascape. The effects of such intense predation are clearly mirrored on the shore, where patches of small mussels on the low shore were almost completely absent outside beds of mature mussels. These findings stand in considerable contrast to the conclusions of Menge et al. (1999, 2002, 2003), who surmised that there was little predation pressure on mussel populations along the east coast of New Zealand's South Island. In fact, one of their study sites, Box Thumb, was used by us during this study. Their conclusion was based on comparisons of predation rates of adult mussels by the large sea star Stichaster australis, which is relatively rare on the east coast but abundant on the west coast. Our study shows that predation on mussel recruits by predators arriving from subtidal habitats at for the $5 \mathrm{~min}$ observation periods). Their average number of bites was $1.7 \pm 1.2$ and $0.3 \pm 0.3$, respectively. These labrids occasionally ventured into the mid-shore zone.

\section{Crab abundance}

Large crabs were not seen on the low- and midshore rocks during the daytime observations described above. Three species and 105 individuals of large crabs were caught in pots laid overnight at $\mathrm{BR}$ and BT. They were the red rock crab Plagusia chabrus Linnaeus $(0.4 \pm 0.2$ and $2.4 \pm 1.0$ per crab pot at $\mathrm{BT}$ and $\mathrm{BR}$, respectively), cancer crabs Cancer novaezelandiae Jacquinot $(3.8 \pm 2.0$ and $10.6 \pm 6.2$, respectively) and the hairy spider crab Notomithrax ursus Herbst $(0.6 \pm 0.2$ and $3.2 \pm 0.9$, respectively). Mean carapace width and height was $6.7 \pm 0.2$ and $3.3 \pm 0.1$, respectively, for red rock crabs and $7.0 \pm$ 0.2 and $2.5 \pm 0.06$ for cancer crabs. The hairy spider crab is very slow and considered to be mainly herbivorous. The larger individuals of both the red and cancer crabs could probably not entirely enter the Partial Cages because their carapace is too thick, but their chelipeds were long enough to reach into the cage.
Table 1. Number of small ( $<5 \mathrm{~mm}$ ) and larger (5 to $15 \mathrm{~mm}$ ) mussel recruits; 2-way ANOVA: effect of site (treated as a random factor) and shore height (low- vs. mid-shore) at BT and BR during March, and of date (January vs. March) and shore level at BR. D: date; S: site; Sh: shore height. Significant p-values in bold

\begin{tabular}{|c|c|c|c|c|c|}
\hline \multicolumn{2}{|c|}{ Source of variation } & $\mathrm{df}$ & MS & $F$ & $\mathrm{p}$ \\
\hline \multicolumn{6}{|c|}{ March } \\
\hline Site & 5056.20 & 1 & 5056.20 & 7.919 & 0.217 \\
\hline Shore height & 1620.00 & 1 & 1620.00 & 2.537 & 0.357 \\
\hline $\mathrm{S} \times \mathrm{Sh}$ & 638.45 & 1 & 638.45 & 1.494 & 0.225 \\
\hline Error & 32482.10 & 76 & 427.40 & & \\
\hline \multicolumn{6}{|c|}{ 5-15 $\mathrm{mm}$ shell length } \\
\hline Site & 1470.61 & 1 & 1470.61 & 0.903 & 0.516 \\
\hline Shore height & 5362.81 & 1 & 5362.81 & 3.292 & 0.321 \\
\hline $\mathrm{S} \times \mathrm{Sh}$ & 1629.01 & 1 & 1629.01 & 7.798 & 0.007 \\
\hline Error & 15876.05 & 76 & 208.90 & & \\
\hline \multirow{2}{*}{\multicolumn{6}{|c|}{$\begin{array}{l}\text { Black Rock } \\
<5 \mathrm{~mm} \text { shell length }\end{array}$}} \\
\hline & & & & & \\
\hline Date & 7334.45 & 1 & 7334.45 & 17.48 & 0.0001 \\
\hline Shore height & 1711.25 & 1 & 1711.25 & 4.08 & 0.0470 \\
\hline $\mathrm{D} \times \mathrm{Sh}$ & 583.20 & 1 & 583.20 & 1.39 & 0.24 \\
\hline Error & 31890.10 & 76 & 419.61 & & \\
\hline \multicolumn{6}{|c|}{ 5-15 mm shell length } \\
\hline Date & 154.01 & 1 & 154.01 & 0.39 & 0.53 \\
\hline Shore height & 16102.81 & 1 & 16102.81 & 40.66 & $<0.0001$ \\
\hline $\mathrm{D} \times \mathrm{Sh}$ & 177.01 & 1 & 177.01 & 0.45 & 0.50 \\
\hline Error & 30099.85 & 76 & 396.05 & & \\
\hline
\end{tabular}


high tide can be so swift that the process could be easily missed. As the first tide was moving in, more than $60 \%$ of the unprotected mussels had already been removed, and fish were observed attacking and removing the remainder. Fish and crabs are not cryptic predators but also are not obvious if observations are confined to low tide periods within the intertidal zone alone. The present study highlights an important contextual perspective. When planning to study biological interactions among functional groups in a specific community, it is important to be familiar with the entire suite of potential interactors and to consider that interactions may occur at specific life stages (e.g. only juveniles) but not others, so that experiments can be designed accordingly. Predatory fish are abundant along the rocky shores of eastern New Zealand (e.g. Choat \& Ayling 1987, Schiel \& Hickford 2001), and mussels are scarce at many wave-exposed locations. This observation alone suggested the potential importance of predation by fish in the intertidal zone. We therefore propose that mussel scarcity at many of these sites is at least partly due to a combination of low settlement rates on the rocky intertidal (as suggested by Menge et al. 1999) and very strong predation on recruits. Furthermore, the configuration of habitats is clearly important. When a rocky intertidal bench is continuous with a deep subtidal reef, it presents a single seascape to highly mobile predators. In a related study, we demonstrated that at sites where intertidal rocky benches are surrounded by shallow sandy bottoms with no nearby subtidal reefs, predation on small intertidal mussels can be very low and small mussels on the low shore are prolific (Rilov \& Schiel 2006).

Subtidal predators would naturally have less foraging time during high tides on the upper reaches of the shore. Indeed, predation on mid-shore mussels was less rapid and intense than on low-shore ones. The experimental results are coherent with other patterns seen at these tidal heights. Settlement rates of mussels in collectors at the 2 shore levels were not significantly different. Within barnacle patches, where recent mussel recruits $(<5 \mathrm{~mm})$ are relatively protected from predation by fish, there was also no difference in their numbers between shore heights. It seems clear, therefore, that mussels settle and recruit in about equal intensities at the low- and mid-shore levels. However, the abundance of late recruits ( 5 to $15 \mathrm{~mm}$, i.e. sizes greater than the height of the barnacle tests) outside mussel beds was much greater at the mid- than the low-shore level, a difference that can be attributed largely to differences in predation intensity by subtidal predators.

It was also clear that large, mobile predators other than fish readily forage across the subtidal-intertidal boundary. Although there were no direct observations of predation by crabs on mussels in this study (they are mostly nocturnal predators), they are the most likely culprits. Crabs are known as intertidal predators elsewhere, mostly on snails (e.g. Moran 1985, Yamada \& Boulding 1996) but also on mussels (e.g. Lohrer \& Whitlatch 2002). Large crabs were common on subtidal reefs in Banks Peninsula, especially the red rock crab Plagusia chabrus and the cancer crab Cancer novaezelandiae. At both our study sites, predation was slower but intense in cages which excluded fish but to which large mobile invertebrates had access. Cancer crabs in New Zealand eat small mussels of the sizes used in our study (Creswell \& McLay 1990), and large red rock crabs readily fed on small mussels in laboratory trials (G. Rilov unpubl. data). In northern New Zealand, red rock crabs are known to travel from the subtidal zone to the intertidal to feed, mostly at night (Almarzah 1985). We observed red rock crabs in the North Island of New Zealand foraging after dark in the intertidal zone and feeding on mussels (G. Rilov \& D. Schiel unpubl. data). Crabs are less mobile than fish and thus can cover less ground during foraging bouts. This was expressed in lower predation rates on mussels in the partial cages than on mussels on tiles exposed to all predators. The high SE of survival on tiles in partial cages indicated that they were 'discovered' by the predators one at a time over a period of a week or two (Fig. 4). Furthermore, predation in the Partial Cages was faster in the site (BR) with the higher abundance of predatory crabs (Fig. 4).

Under such intense predation pressure by both fish and crabs, it is not certain how mussel beds are able to persist at all on some intertidal shores adjacent to subtidal reefs. One hypothesis is that occasional large recruitment episodes occur where the predators are overwhelmed and a single year class comes to dominate the shore. However, $10 \mathrm{yr}$ of recruitment data from 1 of our east coast sites indicate low recruitment levels, with no evidence of major pulses of larval supply (Menge et al. 1999, 2003, B. Menge unpubl. data, G. Rilov unpubl. data). Therefore, the answer probably lies in the fact that, unlike large sea stars such as Pisaster spp. and Stichaster spp. (Paine 1971, Menge et al. 1994, 1999, 2002), labrids tend to eat only small mussels (Hayden 1995). This means that recruits settling in microhabitats that offer protection from predation by fish and crabs may find refuge in size as they grow, if sea stars are rare. Indeed, at most sites on Banks Peninsula that are continuous with subtidal reefs, mussels were located mainly in and around crevices and holes in the rock. Similarly, on mid- and high-shore smooth-rock habitats on the Oregon coast, mussels escape predation by birds only in crevices (Marsh 1986). Escape in size also allows the persistence of blue mussels on subtidal soft bottoms where the abundance 
of small sea stars Asterias rubens is very high (Reusch \& Chapman 1997). Adult mussels also offer refuge from predation by fish (all ranges of sizes are found within patches of large mussels, G. Rilov unpubl. data). Therefore, it appears that as mussels grow above the depth of crevices, they can form a small patch that then offers refuge for recruits at its margins and allows the patch to grow over time. If uninterrupted by natural (e.g. storms) or anthropogenic (mussel harvesting) disturbances, these mussel patches have the potential to grow in size to form more extensive mussel beds on the east coast.

In conclusion, this and a related study (Rilov \& Schiel 2006) offer rare examples experimentally demonstrating that fish on temperate reefs can exert intense predation pressure on intertidal basal species such as mussels. They also show that food-web models that do not include predation on early life stages are incomplete (Menge et al. 1999, 2002), miss important trophic linkages across seascapes, and greatly underestimate the rate, intensity, and effects of predation on intertidal assemblages. It is therefore predictable that in biogeographic regions where shallow subtidal predatory fish and crabs are abundant, small size classes of mussels will be highly vulnerable to predation, mainly at lowshore levels, which will interact with the fine-scale habitat complexity (availability of refuges) to produce mussel bed structure and dynamics. Furthermore, because of great differences in the suite of nearshore predacious fishes, it is highly likely that these effects will vary between the west coast of North America and austral shores. Testing the importance of predation across seascapes in other regions of the world will help resolve issues relating to coastal food-web models that incorporate important post-settlement stages of prey life histories.

Acknowledgements. We thank B. Menge for useful comments on portions of this paper and J. H. Choat for his helpful review. Many thanks to our Marine Ecology Research Group (MERG), R. Taylor, D. Taylor, M. Novak, S. Lillie and S. Goldstien for invaluable help with field work and to N. Ethridge for help in the workshop. This research was financially supported by the Andrew Mellon Foundation including a post-doctoral fellowship to G.R., and the NZ Foundation for Research, Science and Technology.

\section{LITERATURE CITED}

Almarzah GWA (1985) The intertidal and subtidal behavior of the red rock crab Plagusia capensis. MSc thesis, University of Auckland

Barros F, Underwood AJ, Lindegarth M (2001) The influence of rocky reefs on structure of benthic macrofauna in nearby soft-sediments. Estuar Coast Shelf Sci 52:191-199

Bartlett D, Carter RWG (1991) Seascape ecology: the landscape ecology of the coastal zone. Ekologia 10:43-53
Burrows MT, Kawai K, Hughes RN (1999) Foraging by mobile predators on a rocky shore: underwater TV observations of movements of blennies Lipophrys pholis and crabs Carcinus maenas. Mar Ecol Prog Ser 187:237-250

Choat JH, Ayling AM (1987) The relationship between habitat structure and fish faunas on New Zealand reefs. J Exp Mar Biol Ecol 110:257-284

Choat JH, Schiel DR (1982) Patterns of distribution and abundance of large brown algae and invertebrate herbivores in subtidal regions of northern New Zealand. J Exp Mar Biol Ecol 60:129-162

Creswell PD, McLay CL (1990) Handling times, prey size and species selection by Cancer novaezelandiae (Jacquinot, 1853) feeding on molluscan prey. J Exp Mar Biol Ecol 140: $13-28$

Davis N, Vanblaricom GR, Dayton PK (1982) Man-made structures on marine sediments - effects on adjacent benthic communities. Mar Biol 70:295-303

Denny CM, Schiel DR (2001) Feeding ecology of the banded wrasse Notolabrus fucicola (Labridae) in southern New Zealand: prey items, seasonal differences, and ontogenetic variation. NZ J Mar Freshw Res 35:925-933

Edwards DC, Conover DO, Sutter F III (1982) Mobile predators and the structure of marine intertidal communities. Ecology 63:1175-1180

Hayden BJ (1995) Factors affecting recruitment of farmed greenshell mussels, Perna canaliculus (Gmelin) 1791, in Marlborough Sounds. PhD dissertation, University of Otago

Hickerson MJ, Cunningham CW (2005) Contrasting quarternary histories in an ecologically divergent sister pair of low-dispersing intertidal fish (Xiphister) revealed by multilocus DNA analysis. Evolution 59:344-360

Jones GP (1984a) Population ecology of the temperate reef fish Pseudolabrus-Celidotus Bloch and Schneider (Pisces, Labridae). 1. Factors influencing recruitment. J Exp Mar Biol Ecol 75:257-276

Jones GP (1984b) Population ecology of the temperate reef fish Pseudolabrus-Celidotus Bloch and Schneider (Pisces, Labridae). 2. Factors influencing adult density. J Exp Mar Biol Ecol 75:277-303

Jones GP (1988) Ecology of rocky reef fish of northeastern New Zealand: a review. NZ J Mar Freshw Res 22:445-462

Jones GP, Andrew NL (1993) Temperate reefs and the scope of seascape ecology. In: Battershill CN, Schiel DR, Jones GP, Creese RG, MacDiarmid AB (eds) 2nd Int Temperate Reef Symp (7-10 Jan 1992). NIWA Marine, Auckland, p 63-76

Kollman J, Buschor M (2003) Edges effects on seed predation by rodents in deciduous forests of northern Switzerland. Plant Ecol 164:249-261

Levings SC, Garrity SD, Ashkenas LR (1986) Feeding rates and prey selection of oystercatchers in the Pearl Islands of Panama. Biotropica 18:62-71

Lindquist DG, Cahoon LB, Clavijo IE, Posey MH, Bolden SK, Pike LA, Burk SW, Cardullo PA (1994) Reef fish stomach contents and prey abundance on reef and sand substrata associated with adjacent artificial and natural reefs in Onslow Bay, North Carolina. Bull Mar Sci 55:308-318

Lively CM, Raimondi PT (1987) Desiccation, predation, and mussel-barnacle interactions in the northern Gulf of California. Oecologia 74:304-309

Lohrer AM, Whitlatch RB (2002) Relative impacts of two exotic brachyuran species on blue mussel populations in Long Island Sound. Mar Ecol Prog Ser 227:135-144

Lubchenco J, Menge BA, Garrity SD, Lubchenco PJ and 5 others (1984) Structure, persistence, and role of consumers 
in a tropical rocky intertidal community (Taboguilla Island, Bay of Panama). J Exp Mar Biol Ecol 78:23-73

Marsh CP (1986) Rocky intertidal community organization: the impact of avian predators on mussel recruitment. Ecology 67:771-786

Menge BA, Sutherland JP (1987) Community regulation: variation in disturbance, competition, and predation in relation to environmental stress and recruitment. Am Nat 130: 730-757

Menge BA, Lubchenco J, Ashkenas LR, Ramsey F (1986) Experimental separation of effects of consumers on sessile prey in the low zone of a rocky shore in the Bay of Panama - direct and indirect consequences of food web complexity. J Exp Mar Biol Ecol 100:225-269

Menge BA, Berlow EL, Blanchette CA, Navarrete SA, Yamada SB (1994) The keystone species concept: variation in interaction strength in a rocky intertidal habitat. Ecol Monogr 64:249-286

Menge BA, Daley BA, Lubchenco J, Sanford E, Dahlhoff E, Halpin PM, Hudson G, Burnaford JL (1999) Top-down and bottom-up regulation of New Zealand rocky intertidal communities. Ecol Monogr 69:297-330

Menge BA, Sanford E, Daley BA, Freidenburg TL, Hudson G, Lubchenco J (2002) Inter-hemispheric comparison of bottom-up effects on community structure: insights revealed using the comparative-experimental approach. Ecol Res $17: 1-16$

Menge BA, Lubchenco J, Bracken MES, Chan F and 9 others (2003) Coastal oceanography sets the pace of rocky intertidal community dynamics. Proc Natl Acad Sci USA 100: 12229-12234

Moran MJ (1985) The timing and significance of sheltering and foraging behavior of the predatory intertidal gastropod Morula marginalba Blainville (Muricidae). J Exp Mar Biol Ecol 93:103-114

Navarrete SA, Casilla JC (1993) Predation by Norway rats in the intertidal zone of central Chile. Mar Ecol Prog Ser 92: 187-199

Editorial responsibility: Otto Kinne (Editor-in-Chief), Oldendorf/Luhe, Germany
Ojeda FP, Dearborn JH (1991) Feeding ecology of benthic mobile predators - experimental analyses of their influence in rocky subtidal communities of the gulf of Maine. J Exp Mar Biol Ecol 149:13-44

Paine RT (1971) A short-term experimental investigation of resource partitioning in a New Zealand rocky intertidal habitat. Ecology 52:1096-1106

Polis GA, Anderson WB, Holt RD (1997) Toward an integration of landscape and food web ecology: the dynamics of spatially subsidized food webs. Annu Rev Ecol Syst 28: 289-316

Reusch TBH, Chapman ARO (1997) Persistence and space occupancy by subtidal blue mussel patches. Ecol Monogr 67:65-87

Rilov G, Schiel RD (2006) Seascape-dependent subtidalintertidal trophic linkages. Ecology 87:731-744

Robles C (1987) Predator foraging characteristics and prey population-structure on a sheltered shore. Ecology 68: $1502-1514$

Robles C, Sweetnam D, Eminike J (1990) Lobster predation on mussels - shore-level differences in prey vulnerability and predator preference. Ecology 71:1564-1577

Schiel DR, Hickford MJH (2001) Biological structure of nearshore rocky subtidal habitats in southern New Zealand. Sci Conserv 182:5-54

Sokal RR, Rohlf FJ (1995) Biometry. WH Freeman, New York

Stapp P, Polis GA (2003) Marine resources subsidize insular rodent populations in the Gulf of California, Mexico. Oecologia 134:496-504

Underwood AJ (1997) Experiments in ecology; their logical design and interpretation using analysis of variance. Cambridge Univeristy Press, Cambridge

Wootton JT (1991) Direct and indirect effects of nutrients on intertidal community structure: variable consequences of seabird guano. J Exp Mar Biol Ecol 151:139-153

Yamada SB, Boulding EG (1996) The role of highly mobile crab predators in the intertidal zonation of their gastropod prey. J Exp Mar Biol Ecol 204:59-83

Submitted: January 5, 2006; Accepted: April 20, 2006

Proofs received from author(s): November 17, 2006 